\title{
META-ANALISIS EFEKTIVITAS PENGGUNAAN MEDIA ANIMASI DALAM MENINGKATKAN HASIL BELAJAR IPA
}

\author{
Siti Khomaidah ${ }^{1}$, Nyoto Harjono ${ }^{2}$ \\ 1,2 Jurusan PGSD, Universitas Kristen Satya Wacana, Salatiga, \\ e-mail: 292016045@student.uksw.edu
}

\begin{abstract}
ABSTRAK
Tujuan penelitian ini untuk menganalisis penggunaan media animasi terhadap hasil belajar IPA siswa Sekolah Dasar. Dalam penelitian ini metode yang digunakan berupa meta analisis dengan cara menganalisis data-data tentang pengaruh media animasi terhadap hasil belajar IPA siswa Sekolah Dasar. Penelitian ini di awali dengan merumuskan topik penelitian, menelusuri hasil penelitian yang relevan untuk di analisis. Data dikumpulkan dengan menelusuri jurnal online dan skripsi. Data dianalisis dengan menggunakan analisis diskriptif kuantitatif. Berdasarkan hasil analisis penggunaan media animasi pada pembelajaran IPA di Sekolah Dasar mampu meningkatkan hasil belajar IPA siswa Sekolah Dasar mulai dari yang terendah 3.93\% sampai yang tertinggi $98.76 \%$ dengan rata-rata $27.009 \%$.
\end{abstract}

Kata Kunci: Meta analisis, hasil belajar, media animasi.

\begin{abstract}
The purpose of this research to analyze the use of animation media on student learning in elementary school. This research uses meta analysis method with an analysis the animation media tumbling data on student learning. First, formulating research topics tracing research result for analysis. And than data is collected by researching online journals and thesis. The data's analysis use descriptive qualitative. Based on the results of the analysis, animation media users in science learning in elementary school are able to improve students learning outcomes, from the lowest $3,93 \%$ until the highest $98,76 \%$ with an average $27.009 \%$.
\end{abstract}

Keywords: Meta analysis, lerning outcomes, animation media. 


\section{Pendahuluan}

Sistem Pendidikan Nasional Nomor 12 Tahun 2012 pasal 1 Undang-Undang Republik Indonesia menyatakan pendidikan merupakan usaha sadar untuk mewujudkan proses pembelajaran supaya siswa dapat secara aktif mengembangkan potensi dirinya baik spiritual, pengendalian diri, kepribadian diri, kecerdasan, akhlak mulia, dan keterampilan. Pada perkembangan teknologi yang semakin maju di zaman sekarang membuat siswa lebih tertarik menghabiskan waktu untuk bermain game dari pada membaca materi pembelajaran. Untuk menangani hal tersebut guru harus pandai dan kreatif dalam menyampaikan materi pembelajaran, misalnya guru menggunakan media pembelajaran. Media pembelajaran terdapat beberapa macam, misalnya media animasi, audio visual, dan sebagainnya. Media pembelajaran animasi merupakan solusi bagi guru dalam kegiatan pembelajaran untuk meningkatkan hasil belajar IPA siswa yang semula rendah dapat berubah menjadi tingggi. Hal ini dapat terjadi karena siswa dapat melihat, dan mendengarkan materi pembelajaran dengan jelas. Manfaat dari penggunaan media animasi dalam pembelajaran IPA tidak hanya dirasakan oleh siswa tetapi juga dapat dirasakan oleh guru yaitu tidak perlu menghabiskan waktu lama untuk menjelaskan materi pembelajaran dan dapat menarik perhatian siswa, sehingga siswa termotivasi dalam mengikuti kegiatan pembelajaran yang sedang berlangsung. Dalam menggunaan media naimasi guru harus mampu menjelaskan materi pembelajaran secara detal sehingga tidak merasa kebingungan dalam melihat media animasi yang ditayangkan oleh guru.

Animasi berasal dari kata "to animate" yang artinya membuat seolah-olah hidup dan bergerak. Menurut Sulistiyowati (2018) animasi adalah film yang berasal dari gambargambar yang diolah sedemikian rupah hingga menjadi sebuah gambar bergerak dan bercerita. Media animasi yang merupakan bagian dari multimedia tersebut adalah media yang mengandung suara, tulisan dan gambar yang dapat bergerak (Munandar, 2018) . Media animasi ini sering digunakan dalam model simulasi berbasis komputer (Gunawan, 2015). MPBM berbantuan media animasi merupakan modifikasi terhadap MPBM dengan menambahkan media animasi dalam proses pembelajarannya (Santoso, 2016).

Berdasakan hasil penelitian-penelitian yang telah dilakukan tentang pengaruh yang ditimbulkan dari penggunaan media animasi dalam pembelajaran IPA, hal tersebut dapat dilihat dari hasil belajar IPA. Untuk mengetahui tentang pengaruh yang ditimbulkan dari penggunaan media animasi pada pembelajaran IPA, maka penulis melakulam penelitian meta-analisis tentang pengaruh media animasi dalam pembelajaran IPA Sekolah Dasar.

\section{Metode}

Penelitian ini menggunakan jenis penelitian meta analisis. pengumpulan data dilakukan dengan menyelusuri jurnal online, dan skripsi. Dari hasil penelusuran diperoleh 10 artikel dan pengambilan data dilakukan dengan adanya data sebelum dan sesudah tindakan dalam bentuk skor. Analisis yang digunakan adalah kuantitatif. Dapat diambil kesimpulan pengertian dari media animasi merupakan media audio visual yang didalamnya terdapat gambar yang berhubungan dengan materi pembelajaran dengan efek bergerak, dan mempunyai suara. Dalam mendesain media animasi harus menarik dan sesuai dengan materi pembelajaran. Sehingga peserta didik tidak merasa kesulitan dalam memahami materi pembelajaran.

\section{Hasil dan Pembahasan}

Hasil Penelitian yang diikutkan dalam penelitian meta analisis ini antara lain: 1) Pemanfaatan media animasi flas untuk meningkatkan hasil belajar siswa kelas $\mathrm{V}$ mata pelajaran IPA di SD N Lebo Sidorjo oleh Ima Mala Hayati, 2)Efektivitas penggunaan media animasi terhadap hasil belajar siswa kelas $\mathrm{V}$ pada pembelajaran IPA materi pokok pesawat sederhana MI Miftahul Huda Pakis Aji Jepara oleh Nurul Jannah, 3) Pengaruh penggunaan media video animasi terhadap hasil belajar siswa kelas V SD N Segugus Sukodono Sidoarjo 
oleh Laily Rahmawati dan Farida Istianah, 4) Pengembangan media pembelajaran berbasis animasi interaktif pada materi system peredaran darah manusia di MI Raudhatul Ulum Ngijo Karang Ploso Malang oleh Dina Fitriana, 5) Peningkatan hasil belajar IPA melalui pembelajaran kooperatif berbasis konstruktivisme dipadukan dengan video animasi edukasi siswa kelas IV Min V Bandar Lampung oleh Een Subekti, 6) Pemanfaatan media film kartun animasi untuk meningkatkan hasil belajar siswa pada materi daur hidup hewan oleh Hambali, 7) Pengaruh penggunaan media animasi terhadap hasil belajar IPA siswa Slow Learner SD Brawijaya Smart School Malang oleh Ninuk wahyunita sari dan Ahmad samawi, 8) Pengaruh media animasi terhadap hasil belajar IPA siswa kelas 5 pada konsep system peredaran darah oleh Laila Munawaroh, 9) Meningkatkan hasil belajar siswa dengan menggunakan media animasi audio visual Pada mata pelajaran ipa di kelas V SD oleh Nurul Hidayatunnisa, 10) Peningkatan hasil belajar ilmu pengetahuan alam melalui media pembelajaran animasi adobe flash Pada siswa kelas IV SD N 03 Malanggaten oleh Angga Deni Prastowo.

Tabel. 1 Hasil Analisis Media Animasi

\begin{tabular}{|c|c|c|c|c|c|c|}
\hline \multirow{2}{*}{ No } & \multirow{2}{*}{$\begin{array}{c}\text { Topik } \\
\text { Penelitian }\end{array}$} & \multirow{2}{*}{ Peneliti } & \multicolumn{4}{|c|}{ Peningkatan Hasil Belajar } \\
\hline & & & Sebelum & Sesudah & Gain & Gain (\%) \\
\hline 1. & $\begin{array}{l}\text { Media Animasi } \\
\text { Flas, Hasil } \\
\text { Belajar IPA } \\
\text { Kelas V }\end{array}$ & $\begin{array}{l}\text { Ima Mala } \\
\text { Hayati }\end{array}$ & 72 & 83 & 11.0 & 15.27 \\
\hline 2 & $\begin{array}{l}\text { Media animasi } \\
\text {, Hasil Belajar } \\
\text { IPA V }\end{array}$ & Nurul Jannah & 74.95 & 77.9 & 2.95 & 3.93 \\
\hline 3 & $\begin{array}{l}\text { Media video } \\
\text { animasi, Hasil } \\
\text { belajar IPA V }\end{array}$ & $\begin{array}{l}\text { Laily } \\
\text { Rahmawati } \\
\text { dan Farida } \\
\text { Istianah }\end{array}$ & 64.44 & 90 & 25.56 & 39.66 \\
\hline 4 & $\begin{array}{l}\text { Media animasi } \\
\text { interaktif, Hasil } \\
\text { belajar IPA V }\end{array}$ & Dina Fitriana. & 40.5 & 80.5 & 40 & 98.76 \\
\hline 5 . & $\begin{array}{l}\text { Media nimasi } \\
\text { berbasis } \\
\text { kontruktivisme, } \\
\text { Hasil belajar } \\
\text { kelas IV. }\end{array}$ & Een Subekti. & 69.7 & 76.43 & 6.73 & 9.65 \\
\hline 6. & $\begin{array}{l}\text { Media film } \\
\text { kartun } \\
\text { animasi, Hasil } \\
\text { belajar IPA IV }\end{array}$ & Hambali & 71.1 & 85.3 & 14.2 & 19.97 \\
\hline 7. & $\begin{array}{l}\text { Media } \\
\text { Animasi, Hasil } \\
\text { Belajar IPA } \\
\text { siswa Slow } \\
\text { Learner }\end{array}$ & $\begin{array}{l}\text { Ninuk wahyudi } \\
\text { sari dan } \\
\text { Ahmad samawi }\end{array}$ & 61.6 & 80 & 18.4 & 29.87 \\
\hline 8 & $\begin{array}{l}\text { Media } \\
\text { animasi, Hasil } \\
\text { belajar IPA } \\
\text { kelas IV }\end{array}$ & $\begin{array}{l}\text { Laila } \\
\text { Munawaroh }\end{array}$ & 45.59 & 51.28 & 5.69 & 12.48 \\
\hline 9 & $\begin{array}{l}\text { Media animasi } \\
\text { audio visual, } \\
\text { Hasil belajar }\end{array}$ & $\begin{array}{l}\text { Nurul } \\
\text { Hidayatunnisal. }\end{array}$ & 68.91 & 83.44 & 14.53 & 21.08 \\
\hline
\end{tabular}


IPA kelas $\mathrm{V}$

10. Media animasi Angga Deni

64. 74

77.9

13.16

20.32 adoble flash,

Prastowo.

Hail belajar

IPA kelas IV

\begin{tabular}{lllll}
\hline Rata-Rata Pengaruh Media Animasi & 63.353 & 78.575 & 15.222 & 27.099
\end{tabular}

Berdarkan hasil penelitian meta analisis dapat dilihat bahwa media animasi sangat efektif digunakan pada siswa Sekolah Dasar. Hal ini terbukti dari meningkatnya hasil belajar

IPA siswa dari yang nilai rendah sampai nilai tinggi yaitu $3.93 \%$ dan $98.76 \%$. Peningkatan hasil belaar tersebut dapat mempengarahui nilai rata-rata. Terlihat dari yang sebelum menggunakan media animasi yaitu 63.353 dan sesudah menggunakan media animasi yaitu 78.575 .

Tabel 2. Paired Samples Statistics

\begin{tabular}{lll|c|c|c}
\hline & & Mean & $\mathrm{N}$ & Std. Deviation & Std. Error Mean \\
\hline \multirow{2}{*}{ Pair 1 } & sebelum & 63.3530 & 10 & 11.47172 & 3.62768 \\
\cline { 2 - 6 } & sesudah & 78.5750 & 10 & 10.40977 & 3.29186 \\
\hline
\end{tabular}

Tabel.3 Paired Samples Test

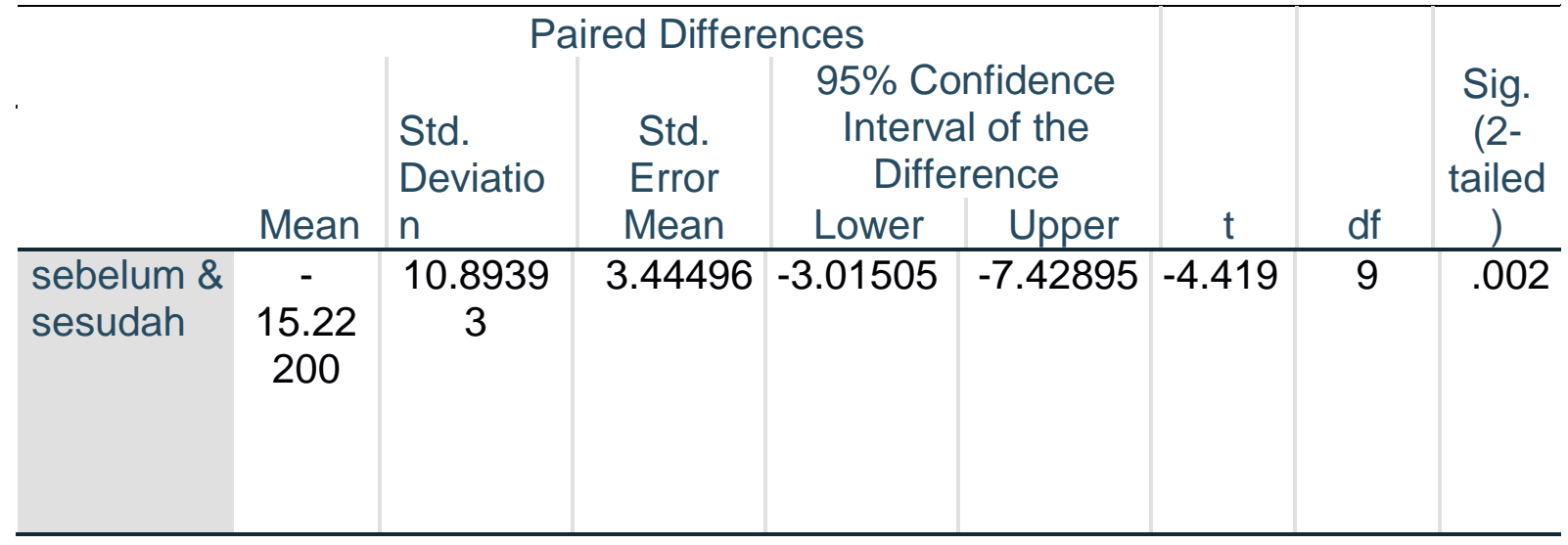

Tabel 2 di atas menunjukan bahwa pembelajaran IPA di Sekolah Dasar (SD) menggunakan media animasi mengalami peningkatan rata-rata sebelum dan sesudah menggunakan media animasi dari rata-rata 63.353 menjadi 78.575. Tabel 3 menunjukan adanya relasi hasil uji hipotesis, $\mathrm{HO}=$ tidak terdapat perbedaan yang signifikan terhadap hasil belajar IPA siswa sebelum menggunakan media animasi dan sesudah menggunakan media animasi dan $\mathrm{H} 1=$ terdapat perbedaan yang signifikan hasil belajar IPA siswa sebelum menggunakan media animasi dan sesudah menggunakan media animasi. Dari tabel 3 tampak bahwa nilai sig (1.47) < (0.05) dan Tabel 4 menunjukan bahwa nilai thitung $=-5.153<$ ttabel $=2.30$ maka Ho ditolak. Jadi dapat disimpulkan bahwa terdapat perbedaan signifikan hasil belajar IPA siswa sebelum dan sesudah menggunakan media animasi.

Pada hasil analisis data tentang efektivitas penggunaan media animasi untuk meningkatkan hasil belajar siswa dapat kita ambil kesimpulan bahwa pembelajaran IPA menggunakan media animasi sangat efektif di gunakan dalam kegiatan pembelajaran. Dengan menggunakan media animasi hasil belajar siswa akan mengalami peningkatan, hal ini terbukti dari nilai rata-rata yang sebelum 
menggunakan media animasi dan sesudah menggunakan media animasi. Pada analisis terdapat presentase yang berbeda-beda dari yang terendah hingga tertinggi.

Perbedaan tersebut dipengaruhi oleh berbagai faktor diantaranya factor internal dan factor eksternal pada siswa. Faktor internal adalah factor yang berasal dari diri individu siswa itu sendiri, seperti halnya kemampuan kognitif, cara berfikir, kemampuan minat dan bakat, serta kesehatan. Sedangkan factor eksternal adalah factor yang berasal dari luar diri individu itu sendiri, seperti lingkungan sekolah, keluarga, teman sebaya, kondisi sekolah, letak sekoah, waktu, dan subjek penelitian.

\section{Simpulan dan Saran}

Berdasarkan hasil pengujian hipotesis dan pembahasan di atas, ditemukan bahwa terdapat perbedaan yang signifikan hasil belajar IPA antara kelompok siswa yang menggunakan pembelajaran dengan menggunakan model pemmbelajaran kooperatif tipe jigsaw berbantuan media gambar dan kelompok siswa yang mengikuti pembelajaran tidak menggunakan model pembelajaran kooperatif tipe jigsaw berbantuan media gambar pada sswa kelas V SD di Gugus V KecamatanBanjar, Kabupaten buleleng tahun ajaran 2017/2018. Hal ini dapat dilihat berdasarkan hasil pengujian hipotesis, diperoleh sebesar 3,292732 , sedangkan dengan $\mathrm{db}=39$ dan taraf signifikansi $5 \%$ adalah 2,022. Hal ini berarti, lebih besar dari $(>)$, sehingga $\mathrm{H}$ ditolak dan $\mathrm{H}$ diterima.

Dengan demikian dapat disimpulkan bahwa pembelajaran dengan menggunakan model pemmbelajaran kooperatif tipe jigsaw berbantuan media gambar berpengaruh positif terhadap hasil belajar IPA siswa kelas V SD di Gugus V Kecamatan Banjar, Kabupaten Buleleng tahun ajaran 2017/2018.

Saran yang dapat disampaikan berdasarkan penelitian yang telah dilakukan adalah sebagai berikut; 1) Bagi Kepala Sekolah, untuk menciptakan kualitas pendidikan yang lebih baik, hendaknya kepala sekolah mengikutsertakan guru untuk mengikuti berbagai seminar atau pelatihan-pelatihan mengenai pembelajaran yang kooperatif, 2) Bagi Guru, diharapkan kepada guru hendaknya memilih pembelajaran yang kooperatif, seperti pembelajaran menggunakan model pembelajaran tipe jigsaw untuk meningkatkan hasil belajar siswa. 3) Bagi Siswa, hendaknya mempertahankan rasa tanggung jawab dalam mengerjakan tugas kelompok dan mengikuti pembelajaran dengan aktif, dan 4) Bagi para peneliti lain yang berminat mengadakan penelitian lebih lanjut dan sejenis tentang pembelajaran kooperatif berbantuan media gambar hendaknya lebih memperhatikan kendala-kendala yang dihadapi siswa dalam pembelajaran serta mengupayakan solusi pemecahan yang tepat agar penelitian yang dilaksanakan dapat mencapai hasil yang lebih maksimal.

\section{Daftar Pustaka}

Fitriana, D. (2014). Pengembangan Media Pembelajaran Berbasis Animasi Interaktif Pada Materi Sistem Peredaran Darah Manusia Di Mi Raudlatul Ulum Ngijo Karangploso Malang . Skripsi. etheses.uin-malang.ac.id/7724/1/10140111.pdf

Gunawan. 2015. Model Pembelajaran Sains Berbasis ICT. Mataram: FKIP PRESS Universitas Mataram.

Hambali. (2015). Pemanfaatan Media Film Kartun Animasi Untuk Meningkatkan Hasil Belajar Siswa Pada Materi Daur Hidup Hewan. Lentera, Vol. 15, No. 15. jurnal.umuslim.ac.id/index.php/LTR1/article/view/641

Hayati, I. m. (2018). Pemanfaatan Media Animasi Flash Untuk Meningktakna Hasil Belajar Siswa Kelas V Mata Pelajaran Ipa Di Sdn Lebo Sidoarjo. Elementary School. Vol. 05, N0. 01. https://media.neliti.com/media/publications/ BIBLIOGRAPHY Im Nur14 VI 1033 Hidayatunnisa, N. (2014). Meningkatkan Hasil Belajar Siswa Dengan Menggunakan Media Animasi Audio Visual Pada Mata Pelajaran IPA Di Kelas V SD Swasta Nasional Al Beringan. Skripsi. digilib.unimed.ac.id/7584/ 
Istianah, L. r. (2018). Pengaruh Penggunaan Media Video Animasi Terhadap Hasil Belajar Siswa Kelas V Sd N Se-Gugus Sukodono Sisoarjo . JPGSD, Vol. 06, No. 4. HYPERLINK "http://jurnalmahasiswa.unesa.ac.id/index.php/jurnal-penelitianpgsd/issue/view/1489" jurnalmahasiswa.unesa.ac.id/index.php/jurnal-penelitianpgsd/issue/view/1489

Jannah, N. (2017). Efektivitas Penggunaan Media Animasi Terhadap Hasil Belajar Siswa Kelas V Pada Pembelajaran Ipa Materi Pokok Pesawat Sederhana Di Mi Miftahul Huda Pakis Aji Jepara. Skripsi. eprints.walisongo.ac.id/7642/

Munawaroh, L. (2015). Pengaruh Media Animasi Terhadap Hasil Belajar Ipa Siswa Kelas 5 Pada Konsep Sistem Peredaran Manusia. Skripsi. repository.uinjkt.ac.id/dspace/bitstream/.../LAILA\%20MUNAWAROH-\%20FITK.pdf

Munandar, H., Sutrio, S. and Taufik, M., 2018. Pengaruh Model Pembelajaran Berbasis Masalah Berbantuan Media Animasi Terhadap Kemampuan Berpikir Kritis dan Hasil Belajar Fisika Siswa SMAN 5 Mataram Tahun Ajaran 2016/2017. Jurnal Pendidikan Fisika dan Teknologi, Volume 4, Nomor 1, pp.111-120.

Prastowo, A. D. (2012). Peningkatan Hasil Belajar IImu Pengetahuan Alam Melalui Media Pembelajaran Animasi Adobe Flash Pada Siswa Kelas Iv Sd N 03 Malanggaten, Kebakkramat, Karanganyar. . Skripsi. eprints.ums.ac.id/19915/1/halaman_depan.pdf

Samawi, N. w. (2014). Pengaruh Penggunaan Media Animasi Terhadap Hasil Belajar Ipa Siswa Slow Learner. P3LB. Vol. 01, N0. $2 . \quad$ HYPERLINK "http://journal.um.ac.id/index.php/jppplb/article/view/5278" journal.um.ac.id/index.php/jppplb/article/view/5278

Santoso, R., Darmadi I. W., dan Darsikin. 2016. Pengaruh Model Pembelajaran Berbasis Masalah Berbantuan Media Komputer terhadap Kemampuan Berpikir Kritis Siswa SMA Negeri 5 Palu. Jurnal Pendidikan Fisika Tadulako. 4 (1): 39-40.

Subekti, E. (2018). Peningkatan Hasil Belajar IPA Melalui Pembelajaran Kooperatif Berbasis Kontruktivisme Dipadukan Dengan Video Animasi Edukasi Siswa Kelas IV Min 5 Bandar Lampung.Skripsi.

HYPERLINK "http://repository.radenintan.ac.id/3882/1/Skripsi\%20Full\%20J.pdf" repository.radenintan.ac.id/3882/1/Skripsi\%20Full\%20J.pdf

Sulistiyowati, T. and Kristanto, A., 2018. Pengembangan Media Video Animasi Tentang Pembentukan Tanah Bagi Siswa Kelas V SD Negeri Singowangi Kec. Kutorejo Kab. Mojokerto. Jurnal Mahasiswa Teknologi Pendidikan, Volume 9, Nomor 2. 